\title{
Trichoptera as bioindicators of habitat integrity in the Pindaíba river basin, Mato Grosso (Central Brazil)
}

\author{
Lilian R. Pereira ${ }^{1 *}$, Helena S. R. Cabette ${ }^{2}$ and Leandro Juen ${ }^{3}$ \\ ${ }^{1}$ Programa de Pós-Graduação em Ciências Ambientais - PPGCA, Cidade Universitária, Bloco CELBE, CEP 78.200-000, \\ Cáceres, MT, Brazil \\ 2 Departamento de Ciências Biológicas, Universidade do Estado de Mato Grosso, BR 158, Km 148, Caixa Postal 08, CEP 78690-000, \\ Nova Xavantina, MT, Brazil \\ ${ }^{3}$ Instituto de Ciências Biológicas, Universidade Federal do Pará, Rua Augusto Correia, No. 1, Bairro Guama, CEP 66.075-110, \\ Belém, PA, Brazil
}

Received 13 July 2011; Accepted 12 May 2012

\begin{abstract}
We evaluated the influence of environmental integrity and the potential as bioindicator of larval stages of species of Trichoptera in 20 streams of first to fourth order in the Pindaíba river basin, Mato Grosso, Central Brazil. We measured stream integrity with the habitat integrity index (HII), establishing three levels of conservation: preserved, altered and impacted environments. We used (i) simple regression to assess the effect of habitat integrity on species abundance of Trichoptera and (ii) the indicator species analysis (IndVal) to assess the potential as bioindicator of each species. We found that 12 morphospecies showed relationship with HII: six species were bioindicators of preserved and two species of altered environments. Morphospecies that showed relationship in the two analyses (i and ii) were considered strong bioindicators, considering that the other species supported higher environmental variation, becoming evident that loss of physical structure reduces the abundance of organisms specialized in preserved environments. The results showed that the distribution and abundance of trichopterans can be an indicator of habitat integrity. Trichopteran species have bioindicator potential, corroborating the hypotheses of this work that abundance of organisms will be smaller in environments with low integrity, and that many species are specific to preserved environments, disappearing from impacted environments, and also characteristic species of altered environments.
\end{abstract}

Key words: Environmental conservation / macroinvertebrates / ecological integrity / Cerrado

\section{Introduction}

Habitat loss changes the biological structure of rivers, directly affecting the composition of aquatic macroinvertebrate and their food resources (Bispo et al., 2006; Nessimian et al., 2008; Dias-Silva et al., 2010). The abundance of some species varies with changes in environmental integrity and even reaching extinction-risk levels (Angermeier and Karr, 1994). Such perturbations in water bodies can exclude specialist species, opening room to the colonization of generalist species (Bahar et al., 2008).

The composition of macroinvertebrates in streams can be used as a parameter to measure environmental conditions (Lammert and Allan, 1999). Species that respond to environmental changes are known as bioindicators, and are very useful in environmental assessment

\footnotetext{
*Corresponding author: lilianrebecca@hotmail.com
}

programs (Niemi and McDonald, 2004; Bonada et al., 2006). Recent studies (e.g., Cortezzi et al., 2009; Utz et al., 2009) showed that a variety of macroinvertebrates can be used as aquatic indicators in sites with agricultural or urban activities.

Some studies demonstrated the effects of anthropic disturbances on the structure and composition of aquatic insects in eastern Mato Grosso state. For example, the environmental integrity and complexity strongly affect the community of larval Odonata (Juen et al., 2007) and a richness of Gerromorpha (Dias-Silva et al., 2010), and Souza et al. (2010) observed that physical changes were the main causes of disruption of beta diversity of Baetidae. Shimano et al. (2010) considered that the removal of gallery forest and dams caused the species loss and decrease in abundance of Ephemeroptera.

Trichopterans along with ephemeropterans and plecopterans are the groups of aquatic insect most used in 
programs of aquatic environment assessment, mainly due to their high richness, ecological diversity and abundance in several types of aquatic habitats (Rosenberg and Resh, 1993; Flint et al., 1999), especially in the lotic systems (Holzenthal et al., 2007). These groups also are important in the trophic dynamics and energy flow in lakes, rivers and streams (Wiggins, 1996).

Trichopterans are very sensitive to changes in physical and chemical structure of aquatic environments (Spies et al., 2006), anthropogenic alteration and variation in canopy cover. Accordingly, these are also the main variables affecting its distribution in the Cerrado (Oliveira and Froehlich, 1997). Additionally, several variables can increase their vulnerability to climatic and environmental changes and extinction risk, such as limited distribution, narrow ecological niche and low dispersal habitability (Hering et al., 2009).

The goal of this study was to evaluate if the distribution and abundance of trichopterans reflect changes in the integrity of streams in eastern Mato Grosso, central Brazil, and select bioindicator species of habitat integrity.

\section{Material and methods}

\section{Study site}

The study was carried out in the Pindaíba river basin, eastern Mato Grosso, central Brazil (between 14 16'46" and $15^{\circ} 57^{\prime} 17^{\prime \prime} \mathrm{S} ; 51^{\circ} 26^{\prime} 37^{\prime}$ and $\left.52^{\circ} 37^{\prime} 03^{\prime} \mathrm{W}\right)$. We sampled five streams: Taquaral (TS), Papagaio (PS), Cachoeirinha (CS), da Mata (MS) and Caveira (CVS; Fig. 1). The Pindaíba river basin is a tributary of das Mortes river, with approximately $10029 \mathrm{~km}^{2}$ of area. The predominant economic activity in this region is extensive livestock.

The regional climate is classified as Cwa according to Köppen classification (Brasil, 1981), with two well-defined seasons: a dry period, from May to September, and a rainy period, from December to March. The mean annual rainfall varies from 1200 to $1600 \mathrm{~mm}$ and mean temperature varies about $20-25^{\circ} \mathrm{C}$, with September and October the warmest months.

\section{Data sampling}

The sampling was taken in first-, second-, third- and fourth-order streams (following Strahler, 1957), with a total of 20 sampling sites. Samplings were carried out in TS, PS and CS streams during 2005, and between 2007 and 2008 in MS and CVS streams. To reduce the effect that seasonal variation in the community of Trichoptera, samples were collected in three seasons: rainy season (January), dry (July-August) and beginning of the rainy season (from September and November), with a total of 60 samples. Due to the high variability of climatic changes during the year, we assumed that there was no autocorrelation of residuals due to temporal pseudoreplication (Hurlbert, 1984).
We collected trichopteran larvae with a $18-\mathrm{cm}$ diameter sieve and $250 \mu \mathrm{m}$ mesh, mounted on dip-net, based on training the net over the bottom, in 100-m linear transects, subdivided into 20 stretches of $5 \mathrm{~m}$ each (after FerreiraPeruquetti and De Marco, 2002). We collected the substrate at the stream margin three times in each stretches.

We used several identification keys to species and morphospecies of Trichoptera (Angrisano, 1995; Wiggins, 1996; Holzenthal and Pes, 2004; Pes et al., 2005, 2008). Specimens were preserved in $85 \%$ alcohol and are housed at the Coleção Zoobotânica James Alexander Ratter (CZNX), Universidade Estadual do Mato Grosso, Nova Xavantina, MT, Brazil. The number of morphotypes follows the records in this collection.

We estimated the environmental integrity of streams using the habitat integrity index (HII) (Nessimian et al., 2008). This index is based on the measurement of several visually assessed parameters related to land use, riparian zone conservation, streambed characteristics, and characteristics of stream channel morphology related to margin and streamlet bed structure. Then, the index is directly related to the degree of environmental conservation and has been successfully used in other studies to evaluate the integrity in aquatic systems (Dias-Silva et al., 2010; Shimano et al., 2010; Juen and De Marco, 2011; Nogueira et al., 2011; Souza et al., 2011).

We initially calculated the HII in an ordinal scale and later converted it to a continuous scale from 0 to 1 . Subsequently, we used the quantitative HII to establish three conservation categories: preserved, altered and impacted environments, according to field observations. Lastly, we used these categories to identify indicator organisms of environmental integrity.

\section{Conservation categories}

Impacted environments were sites with HII between 0.51 and 0.66 , with a total of eight sites (CS_1, CS_4, CVS_1, CVS_4, PS_2 and TS_4). Due to heavy agricultural mechanization, the gallery forest at both margins of these streams are highly deforested, replaced by pastures or soy monoculture, cattle raising. Other processes, such as erosion and silting are also observed. Since stream margins are exposed, the river channel lacks retention mechanisms and consequently little deposited organic material. This situation is even worse in CRC_1, an intermittent stream in a flat area, with high cattle trampling, and the entire CVS stream, dammed at several places, becoming a semi-lotic environment.

Altered environments had HII between 0.69 and 0.78 , and corresponded to five sites (CS_2, CS_3, PS_3, PS_4 and TS_3). Environmental changes measured in this study refer mainly to changes due to partial removal of marginal vegetation, cattle raising, or farming activities. At these points, part of the gallery forest was maintained at least in one of the margins and beyond the riverside zone. Furthermore, there are Cerrado patches among pasture areas, riparian vegetation varied between 5 and $30 \mathrm{~m}$ in 

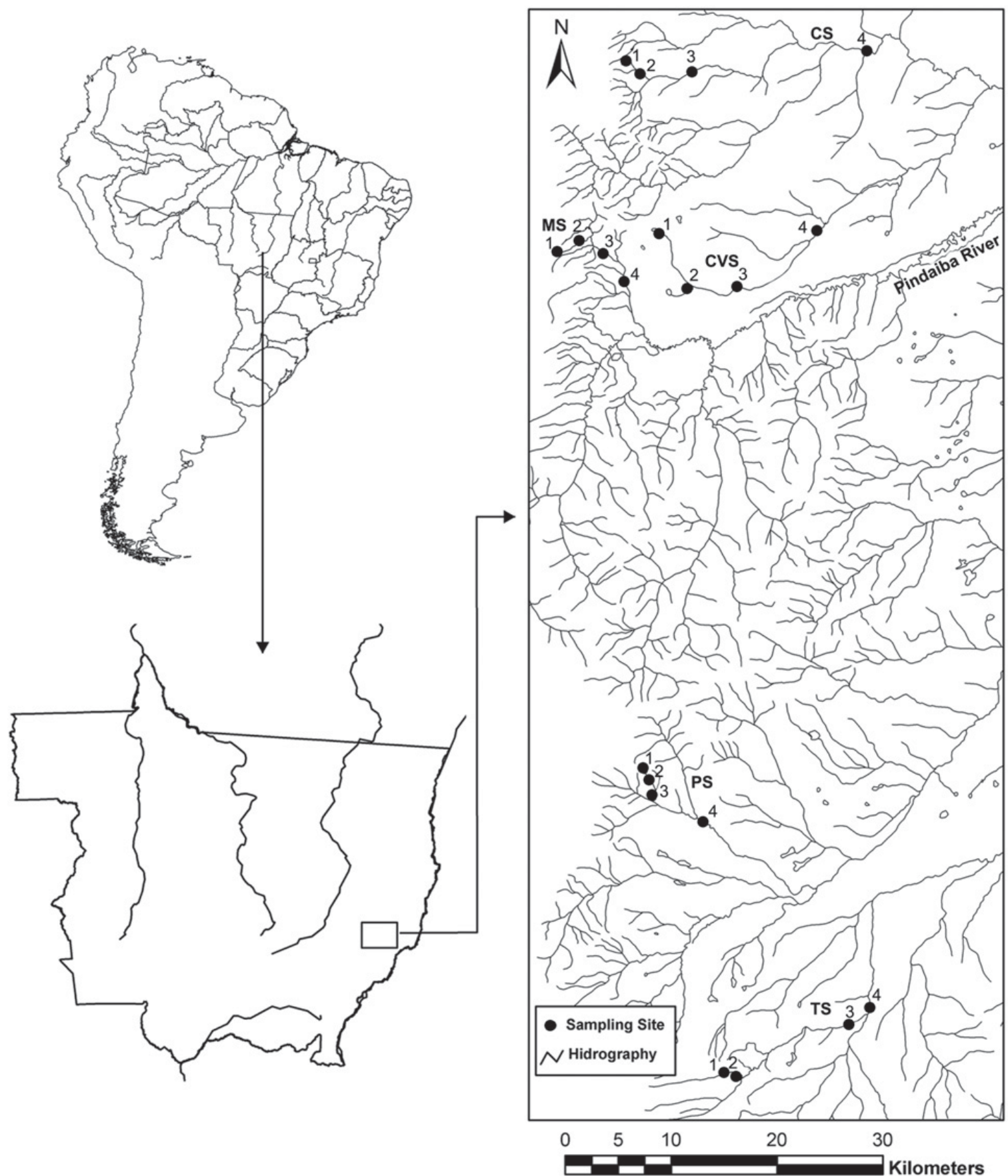

Fig. 1. Sampling sites in the Pindaíba river basin, Mato Grosso, Brazil. CS: Cachoeirinha stream; CVS: Caveira stream; MS: da Mata stream; PS: Papagaio stream; TS: Taquaral stream. The numbers 1, 2, 3 or 4 indicate streams orders.

width, there was retention mechanisms in the water course, such as stones and trunks, stable banks with some cutting, riverbed with silt, gravel and sand, and in some sites, leaf detritus and woody material with sediments.

Preserved environments had HII varying from 0.82 to 0.96 , with a total of seven sites (MS_1-MS_4, PS_1, TS_1 and TS_2). At these points, the predominant characteristics were: more than $50 \mathrm{~m}$ in width of gallery forest, continuously with the adjacent forest, retention mechanisms strongly fixed, lack of banks, little or no accumulation of sediments, riverbed, with stones grouped together, mosses and algae patches, and leaf detritus and woody material without sediment.

\section{Data analysis}

We used a canonical correspondence analysis (CCA; Ter Braak, 1986) to test for a relationship between environmental variables and morphospecies of Trichoptera. 
We used the species abundance in each stream and the matrix of environmental variables with physico-chemical HII, $\mathrm{pH}$, conductivity, water hardness, width and depth of the channel. We used only species with 10 or more individuals [see Appendix 1 (available in the online version) for species abundance used in CCA]. This procedure is considered appropriate in ordination techniques in general, since rarity or low density increases the volume of calculations, causing interpretation errors. The removal of rare species does not affect the results in a relevant way. After a preliminary analysis, we eliminated turbidity, dissolved oxygen, phosphorus and water temperature, because they had a low correlation with the ordination axes and the analysis was rerun. The biotic and environmental factors (except $\mathrm{pH}$ ) were log-transformed in the case of the abundance matrix $\log (x+1)$.

To test for the significance of the CCA axes, we used a Monte Carlo permutation test (Ter Braak, 1986). Analyses were performed in the $\mathrm{R}$ environment ( $\mathrm{R}$ Development Core Team, 2010).

To evaluate the effect of environmental integrity on trichopterans, we used a simple linear regression (Zar, 1999). The independent variable was the HII and the dependent variable was species/morphospecies with 10 or more individuals. The use of species with minimal abundance of 10 individuals is necessary because of rarity to be very common in aquatic communities and, thus, it would be very difficult to meet the assumptions of statistical tests.

We analyzed the bioindicator potential of trichopteran species/morphospecies using the Indicator Value Method (IndVal; Dufrêne and Legendre, 1997). This index measures the degree of specificity (relationship of a species with a specific variable) and the degree of species fidelity (every time that some condition was met, the species was present) in relation to some environmental category. In this study, the variables used were integrity levels of sampling sites (preserved, altered and impacted).

\section{Results}

We collected 5383 trichopteran larvae, belonging to 10 families (Appendix 1 available in the online version). We identified 19 genera and 66 species/morphospecies. The genus Nectopsyche was the most abundant (3732 individuals) and also the most speciose (eight species).

Among the species/morphospecies with 10 or mode individuals $(N=30), 12$ were related to HII and eight were considered indicators of environmental integrity (Table 1).

The total variance in the trichopteran larvae community determined by CCA was 3.826 . The total variance or inertia indicates the total amount of variability potentially explained. The first three correlations between the biotic and abiotic dataset were $0.946,0.917$ and 0.837 , respectively. The first three CCA axes accounted for $27.6 \%$ of the variation of the trichopteran larvae community. Monte Carlo simulations demonstrated that the first three axes were significant (Table 2).
CCA demonstrated that HII and $\mathrm{pH}$ were negatively correlated and width and depth of channel were positively correlated with the first axis. Conductivity and water hardness were positively correlated and nitrate was negatively correlated with the second axis (Table 2).

The following patterns can be described to species/ morphospecies: Chimarra sp. 6, Leptonema sp. 1, Marilia sp. 2, Nectopsyche sp. 1, Phylloicus sp. 2, Polycentropus sp. 1 and Smicridea sp. 5 occurred in streams with high index of habitat integrity. Chimarra sp. 4, Chimarra sp. 5, Helicopsyche sp. 3, Leptonema maculatum Mosely, 1933, Macronema sp. 2, Marilia sp. 1, Oecetis sp. 2, Phylloicus sp. 5, Smicridea sp. 6 and Triplectides sp. 1 occurred in wider and deeper streams, with low HII. Helicopsyche sp. 4, Notalina sp. 1 and Polyplectropus sp. 2 occurred in streams with high $\mathrm{pH}$. The optima of Cernotina sp. 1 and Polyplectropus sp. 4 in the second CCA axis was in the streams with high conductivity and water hardness, whereas Macrostemum sp. 1 and Triplectides sp. 2 were more abundant in the sites with high nitrate (Fig. 2). Eleven species showed positive relationship with environmental integrity (Chimarra sp. 6, Helicopsyche sp. 4, Leptonema sp. 1, Marilia sp. 1 and sp. 2, Nectopsyche sp. 1, Notalina sp. 1, Phylloicus sp. 2, Polycentropus sp. 1, Polyplectropus sp. 2 and sp. 4). Only Macronema sp. 9 was negatively related with integrity, with higher abundance in environments with less integrity.

Helicopsyche sp. 4, Marilia sp. 2, Nectospyche sp. 1, Notalina sp. 1, Phylloicus sp. 2 and Polycentropus sp. 1 can be considered indicators of preserved sites (IndVal). Helicopsyche sp. 3 and Macronema sp. 2 can be considered indicators of altered sites. No species was indicators of impacted environments.

\section{Discussion}

Establishing quick and appropriate ways to measure impacts is essential to recover and preserve natural resources. In this regard, biomonitoring can efficiently assess species loss and the synergistic effects of anthropogenic activities (Rosenberg and Resh, 1993; Buss et al., 2003). We found that filter-collecting morphospecies (Chimarra sp. 6, Leptonema sp. 1, Polyplectropus sp. 2 and Polyplectropus sp. 4) were positively related with environmental integrity, but they were not considered good bioindicators (Merritt and Cummins, 1984; Cummins et al., 2005). Several studies postulated that these genera would be present in riffle areas, e.g., associated Polyplectropus (Martins-Silva et al., 2008), Chimarra (Wiggins, 1996) and Leptonema (Baptista et al., 1998). In our study site, these genera occurred in both preserved and altered environments, but the low abundance and narrow distribution of Chimarra sp. 6 and Polyplectropus sp. 2 do not make them good indicators. The broader distribution of Leptonema sp. 1 and Polyplectropus sp. 4 in both preserved and altered environments, and the lack of fidelity to one of the two types of conservation categories may explain why these 
Table 1. HII related to morphospecies (simple linear regression) and species (IndVal) bioindicator of conservation status, Pindaíba river basin, 2005 and 2007-2008 (IV: indicator value of morphospecies; A: altered; P: preserved; - : absence of indication). Numbers in bold indicate significant results.

\begin{tabular}{|c|c|c|c|c|c|c|c|c|}
\hline \multirow[b]{2}{*}{ Species/morphospecies } & \multicolumn{3}{|c|}{ Regression } & \multicolumn{5}{|c|}{ IndVal } \\
\hline & $r^{2}$ & $P$ & Equation & IV & Mean & SD & $P$ & Indicator \\
\hline Cernotina sp. 1 & 0.185 & 0.058 & $y=-0.524+1.153 x$ & 39.7 & 34.5 & 9.20 & 0.252 & - \\
\hline Chimarra sp. 4 & 0.016 & 0.596 & $y=0.490-0.402 x$ & 12.2 & 23.6 & 10.87 & 0.914 & - \\
\hline Chimarra sp. 5 & 0.033 & 0.441 & $y=0.443-0.423 x$ & 11.3 & 21.1 & 10.47 & 0.855 & - \\
\hline Chimarra sp. 6 & 0.220 & 0.037 & $y=-0.910+1.412 x$ & 28.6 & 16.3 & 9.42 & 0.169 & - \\
\hline Helicopsyche sp. 3 & 0.008 & 0.710 & $y=0.057+0.189 x$ & 49.6 & 28.4 & 10.42 & 0.050 & $\mathbf{A}$ \\
\hline Helicopsyche sp. 4 & 0.355 & 0.006 & $y=-0.844+1.425 x$ & 56.6 & 26.8 & 10.60 & 0.021 & $\mathbf{P}$ \\
\hline Leptonema maculatum & 0.008 & 0.715 & $y=0.228-0.191 x$ & 9.0 & 16.1 & 9.21 & 0.762 & - \\
\hline Leptonema sparsum & 0.077 & 0.238 & $y=1.000-0.894 x$ & 35.3 & 31.5 & 9.60 & 0.287 & - \\
\hline Leptonema sp. 1 & 0.377 & 0.004 & $y=-1.211+2.342 x$ & 45.2 & 34.2 & 8.82 & 0.114 & - \\
\hline Macronema sp. 1 & 0.155 & 0.086 & $y=-0.599+1.359 x$ & 36.8 & 32.9 & 9.32 & 0.295 & _- \\
\hline Macronema sp. 2 & 0.009 & 0.699 & $y=0.471-0.207 x$ & 61.5 & 33.8 & 8.51 & 0.005 & $\mathbf{A}$ \\
\hline Macronema sp. 9 & -0.198 & 0.049 & $y=0.945-1.085 x$ & 30.9 & 20.9 & 10.36 & 0.127 & - \\
\hline Macrostemum sp. 1 & 0.011 & 0.659 & $y=-0.086+0.376 x$ & 12.8 & 21.6 & 10.87 & 0.782 & - \\
\hline Marilia sp. 1 & 0.279 & 0.017 & $y=-1.157+2.430 x$ & 40.7 & 33.8 & 8.82 & 0.187 & - \\
\hline Marilia sp. 2 & 0.437 & 0.002 & $y=-1.618+2.697 x$ & $\mathbf{5 7 . 1}$ & 26.7 & 10.33 & 0.013 & $\mathbf{P}$ \\
\hline Nectopsyche sp. 1 & 0.317 & 0.010 & $y=-2.534+4.376 x$ & 68.0 & 35.1 & 11.20 & 0.015 & $\mathbf{P}$ \\
\hline Notalina sp. 1 & 0.266 & 0.020 & $y=-0.592+0.919 x$ & 42.9 & 19.4 & 10.19 & 0.040 & $\mathbf{P}$ \\
\hline Oecetis sp. 2 & 0.024 & 0.511 & $y=-0.059+0.269 x$ & 19.4 & 25.1 & 10.49 & 0.639 & - \\
\hline Phylloicus sp. 2 & 0.735 & 0.000 & $y=-2.501+4.030 x$ & 83.5 & 32.1 & 10.25 & 0.000 & $\mathbf{P}$ \\
\hline Phylloicus sp. 6 & 0.016 & 0.593 & $y=0.403-0.259 x$ & 45.4 & 29.6 & 9.64 & 0.078 & - \\
\hline Polycentropus sp. 1 & 0.415 & 0.002 & $y=-1.679+2.560 x$ & 42.9 & 19.0 & 10.36 & 0.038 & $\mathbf{P}$ \\
\hline Polyplectropus sp. 2 & 0.247 & 0.026 & $y=-0.763+1.279 x$ & 35.0 & 25.6 & 10.90 & 0.187 & - \\
\hline Polyplectropus sp. 3 & 0.011 & 0.666 & $y=0.024+0.1681 x$ & 18.5 & 26.3 & 10.19 & 0.733 & - \\
\hline Polyplectropus sp. 4 & 0.254 & 0.023 & $y=-0.875+1.520 x$ & 39.8 & 26.8 & 10.54 & 0.110 & - \\
\hline Smicridea (R.) sp. 6 & 0.042 & 0.384 & $y=-0.220+0.635 x$ & 18.5 & 25.0 & 10.38 & 0.694 & - \\
\hline Smicridea (S.) palifera & 0.038 & 0.413 & $y=-0.220+0.669 x$ & 28.6 & 26.7 & 10.41 & 0.364 & - \\
\hline Smicridea (S.) sp. 5 & 0.089 & 0.200 & $y=-0.6316+1.231 x$ & 15.1 & 23.4 & 10.74 & 0.759 & - \\
\hline Smicridea (S.) sp. 6 & 0.012 & 0.641 & $y=0.221-0.208 x$ & 8.6 & 17.1 & 8.70 & 1.000 & - \\
\hline Triplectides sp. 1 & 0.012 & 0.648 & $y=0.025+0.278 x$ & 20.6 & 28.7 & 10.45 & 0.778 & - \\
\hline Triplectides sp. 2 & 0.147 & 0.096 & $y=-0.448+0.802 x$ & 29.2 & 23.1 & 10.56 & 0.198 & - \\
\hline
\end{tabular}

Table 2. Results of CCA for trichopterans collected in streams of the Pindaíba river basin, Mato Grosso, Brazil. Correlation between sample scores for an axis derived from the taxa data and the sample scores that linear combinations of the environmental variables; and ${ }^{*} P<0.01$ (Monte Carlo, 1000 permutations).

\begin{tabular}{lccc}
\hline Total variance ("inertia") & \multicolumn{3}{c}{3.826} \\
\cline { 2 - 4 } in the taxa data & Axis I & Axis II & Axis III \\
\hline Eigenvalue & $0.472^{* *}$ & $0.340^{* *}$ & $0.245^{* *}$ \\
Variance in taxa data & & & \\
\% of variance explained & 12.3 & 8.9 & 6.4 \\
$\quad$ Cumulative \% explained & 12.3 & 21.2 & 27.6 \\
Pearson correlations, & $0.946^{* *}$ & $0.917^{* *}$ & $0.837^{* *}$ \\
Taxon-Env & & & \\
"Intra set correlations" & & & \\
HII & $\mathbf{- 0 . 8 8 7}$ & -0.098 & 0.282 \\
pH & $\mathbf{- 0 . 6 0 4}$ & 0.234 & -0.381 \\
Conductivity & -0.327 & $\mathbf{0 . 6 3 0}$ & -0.368 \\
Nitrate & 0.259 & $\mathbf{- 0 . 5 9 1}$ & 0.631 \\
Water hardness & -0.372 & $\mathbf{0 . 4 5 5}$ & 0.221 \\
Width & $\mathbf{0 . 5 0 8}$ & 0.38 & 0.291 \\
Depth & $\mathbf{0 . 6 3 9}$ & 0.111 & -0.037 \\
\hline
\end{tabular}

species were not recovered as good indicators in the IndVal analysis. Among them, only Chimarra sp. 6 and Leptonema sp. 1 were strongly associated with HII. The other genera were related to hardness and conductivity.

The abundance of Helicopsyche sp. 4, Marilia sp. 2, Nectospyche sp. 1, Notalina sp. 1, Phylloicus sp. 2 and Polycentropus sp. 1 increased as HII increase, which makes them bioindicators of preserved environments. Except for Helicopsyche, which is a periphyton scraper in small streams (Merritt and Cummins, 1984; Holzenthal et al., 2007) and Polycentropus, which is a predator, but include algae in its diet (Reiso and Brittain, 2000), all the previous species are shredders.

Previous studies (Holzenthal et al., 2007; Nessimian et al., 2008) found that Helicopsyche was related to environments of high integrity, containing stones with periphyton, an important resource for its diet. Holzenthal and Hamilton (1988) found that Polycentropus had a limited distribution in forested streams, mostly of clear water, rapid flow and relatively no pollution. Our data for this genus are in accordance with their results. A previous study in the same study area (Dias-Silva et al., 2010) found 


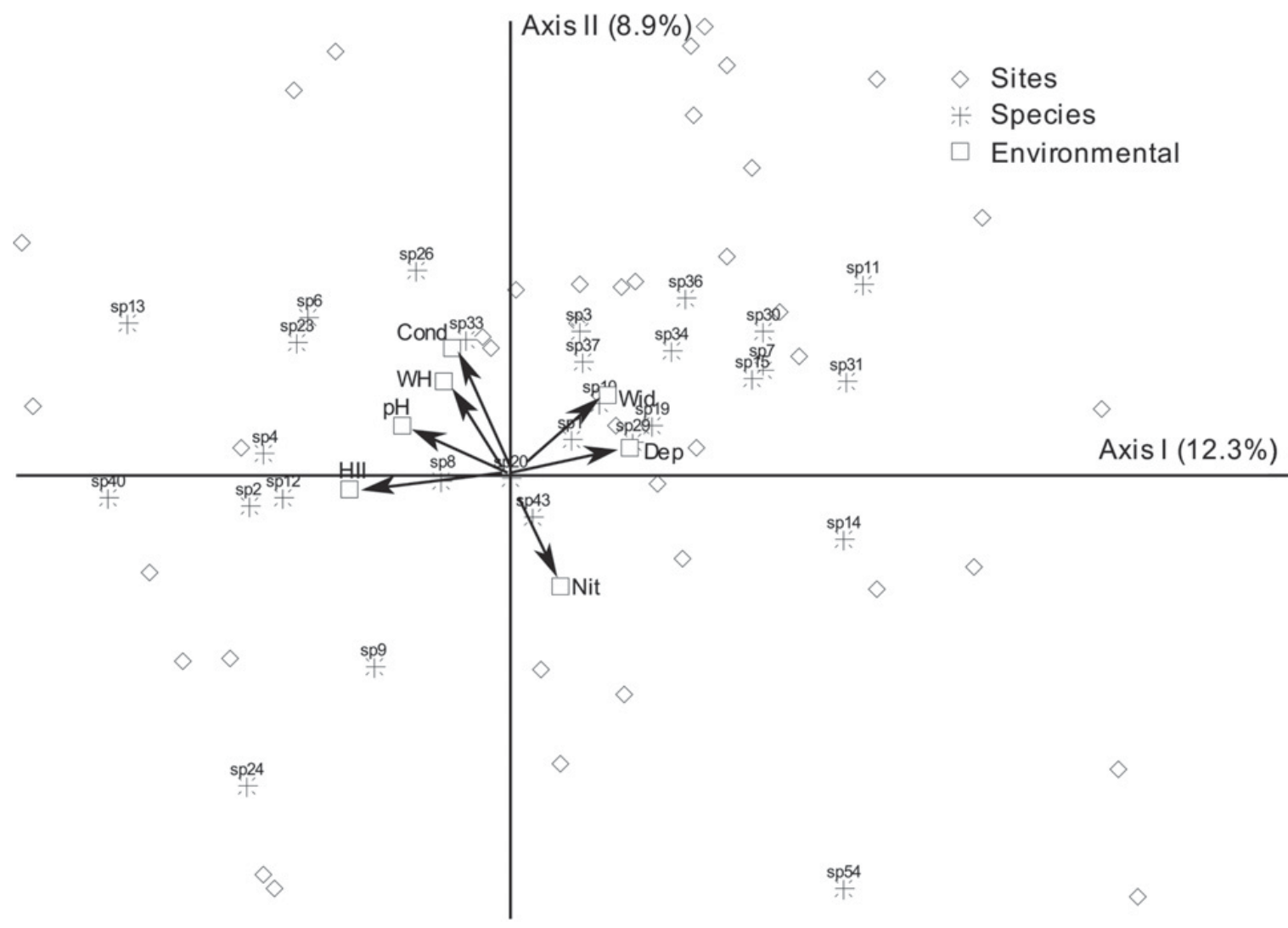

Fig. 2. Scores of CCA for trichopterans and environmental variables recorded along streams in the Pindaíba river Basin, Nova Xavantina, Mato Grosso. The abbreviations of taxa names are listed in Appendix 1 available in the online version. Habitat integrity index (HII), hydrogenionic potential (pH), conductivity (Cond), nitrate (Nit), water hardness (WH), channel width (Wid), depth of the channel (Dep).

that sites with higher integrity had higher richness of predator species of Gerromorpha.

Marilia sp. 2, a shredder species, was distributed in five preserved sites and is confirmed as potential bioindicator. Another study (Couceiro et al., 2007) showed that Marilia was an indicator of non-impacted streams. The results also reinforce other evidence that species of Nectopsyche and Phylloicus are inhabitants of sites of high environmental heterogeneity (Crisci-Bispo et al., 2007). Specifically, Nectopsyche species occurs mainly in riffle areas (CrisciBispo et al., 2004) and Phylloicus species occurs in leaf litter in slow flowing sites, building shelter with pieces of these leaves (Pather, 2003).

Baptista et al. (2001) observed that Notalina was related to physical characteristics of upper parts of rivers, being always associated with litter deposits. In this study, Notalina occurred in preserved environments, but in low abundance. Conserved gallery forests are responsible for the allochthonous matter, generating detritus mainly from leaves and woody material, benefiting shredders (Silveira et al., 2006).

Recovering shredders as bioindicators (HII + IndVal) indicate especially intact riparian forest with adjacent forest in first-order streams. Not surprisingly, we found the highest abundances of Nectopsyche sp. 1 and
Phylloicus sp. 2 in such sites. On the other hand, Macronema sp. 2 and Helicopsyche sp. 3 were little abundant in altered sites, even though they were recovered as indicator species of environments with some alteration.

Species of Macronema seem to be little selective, since they do not show preference for subtrates (Fidelis et al., 2008), but occurs commonly in roots (Flint and BuenoSoria, 1982). This low selectivity can favor the occurrence of Macronema sp. 2 in altered sites. Indeed, there was an increase in abundance of Macronema sp. 9 as HII decreases, indicating that this is a tolerant species.

The recovering of Helicopsyche sp. 3 as an indicator species may be related to increase of light input as a result of reduced riparian forest, along with an increase in width and flow due to the order of altered sites, reducing shading and increasing primary production, essential for scrapers.

Our results indicate that trichopterans are highly related to habitat integrity. The six morphospecies whose abundances were influenced by HII and considered indicators of environmental conditions should be identified to the species level. The advantage of using this taxonomic level is straightforward: species of the same genus have different levels of stress tolerance, and several morphospecies of one genus may have different indicator values, distribution and abundances. 
Acknowledgements. Y. Shimano and D. S. Nogueira reviewed the manuscript and offered useful comments. We also thank F. M. V. Carvalho for the English translation of the manuscript. Diogo B. Provete reviewed the English language at later versions. We are grateful for the support of students and researchers of the former Laboratório de Entomologia (UNEMAT). L. R. Pereira received a CAPES-DS/FAPEMAT Master's fellowship. The research was partially funded by FAPEMAT 0907/2006 and PROCAD 109/2007.

\section{References}

Angermeier P.L. and Karr J.R., 1994. Biological integrity versus biological diversity as policy directives. Bioscience, 44, 690-697.

Angrisano E.B., 1995. Insecta Trichoptera. In: Lopretto E.C. and Tell G. (eds.), Ecossistemas de aguas continentales, metodologia para su estúdio, Ediciones Sul, La Plata, 1199-1227.

Bahar M.D.M., Ohmori H. and Yamamuro M., 2008. Relationship between river water quality and land use in a small river basin running through the urbanizing area of Central Japan. Limnology, 9, 19-26.

Baptista D.F., Dorvillé L.F.M., Buss D.F., Nessimian J.L. and Soares L.H.J., 1998. Distribuição de comunidades de insetos aquáticos no gradiente longitudinal de uma bacia fluvial do sudeste brasileiro. Oecol. Bras., 5, 191-207.

Baptista D.F., Dorvillé L.F.M., Buss D.F. and Nessiamian J.L., 2001. Spatial and temporal organization of aquatic insects assemblages in the longitudinal gradient of a tropical river. Braz. J. Biol., 61, 295-304.

Bispo P.C., Oliveira L.G., Bini L.M. and Souza K.G., 2006. Ephemeroptera, Plecoptera and Trichoptera assemblages from riffles in mountain streams of Central Brazil: environmental factors influencing the distribution and abundance of immatures. Braz. J. Biol., 66, 611-622.

Bonada N., Prat N., Resh V.H. and Statzner B., 2006. Developments in aquatic insect biomonitoring: a comparative analysis of recent approaches. Annu. Rev. Entomol., 51, 495-523.

Brasil, 1981. Projeto RADAMBRASIL, Folha SD 22. Goiás: geologia, geomorfologia, pedologia, vegetação, uso potencial da terra, Ministério das Minas e Energia/Divisão de Publicação, Brasília, 636 p.

Buss D.F., Baptista D.F. and Nessimian J.L., 2003. Bases conceituais para a aplicação de biomonitoramento em programas de avaliação da qualidade da água de rios. Cader. Saúde Públ., 19, 465-473.

Cortezzi S.S., Bispo P. da C., Paciencia G. de P. and Leite R.C., 2009. Influencia da ação antrópica sobre a fauna de macroinvertebrados aquáticos em riachos de uma região do Cerrado do sudoeste do Estado de São Paulo. Iheringia, Sér. Zool., 99, 36-43.

Couceiro S.R.M., Hamada N., Luz S.L.B., Forsberg B.R. and Pimentel T.P., 2007. Deforestation and sewage effects on aquatic macroinvertebrates in urban stream in Manaus, Amazonas, Brazil. Hydrobiologia, 575, 271-284.

Crisci-Bispo V.L., Bispo P.C. and Froehlich C.G., 2004. Triplectides larvae in empty cases of Nectopsyche (Trichoptera, Leptoceridae) at Parque Estadual Intervales, São Paulo State, Brazil. Revta Bras. Ent., 48, 133-134.
Crisci-Bispo V.L., Bispo P.C. and Froehlich C.G., 2007. Ephemeroptera, Plecoptera and Trichoptera assemblages in two Atlantic rainforest streams, Southeastern Brazil. Revta Bras. Zool., 24, 312-318.

Cummins K.W., Merrit R.W. and Andrade C.N., 2005. The use of invertebrate functional groups to characterize ecosystem attributes in selected stream in rivers in southeast Brazil. Stud. Neotrop. Fauna Environ., 40, 71-90.

Dias-Silva K., Cabette H.S.R., Juen L. and De Marco P. Jr., 2010. The influence of habitat integrity and physicalchemical water variables on the structure of aquatic and semi-aquatic Heteroptera. Zoologia, 27, 918-930.

Dufrêne M. and Legendre P., 1997. Species assemblages and indicator species: the need for a flexible asymmetrical approach. Ecol. Monogr., 67, 345-366.

Ferreira-Peruquetti P. and De Marco P. Jr., 2002. Efeito da alteração ambiental sobre comunidades de Odonata em riachos de Mata Atlântica de Minas Gerais, Brasil. Revta Bras. Zool., 19, 317-327.

Fidelis L., Nessimian J.L. and Hamada N., 2008. Distribuição espacial de insetos aquáticos em igarapés de pequena ordem na Amazônia Central. Acta Amazon., 38, 127-134.

Flint O.S. Jr. and Bueno-Soria J., 1982. Studies of neotropical caddisflies, XXXII: The immature stages of Macronema variipenne Flint \& Bueno, with the division of Macronema by the resurrection of Macrostemum (Trichoptera: Hydropsychidae). Proc. Biol. Soc. Wash., 95, 358-370.

Flint O.S. Jr., Holzenthal R.W. and Harris S.C., 1999. Catalog of the Neotropical Caddisflies (Insecta: Trichoptera), Ohio Biological Survey, Columbus, OH, 239 p.

Hering D., Schmidt-Kloiber A., Murphy J., Lucke S., ZamoraMuños C., Lópes-Rodrígues M.J., Huber T. and Graf W., 2009. Potential impact of climate change on aquatic insects: a sensitivity analysis for European caddisflies (Trichoptera) based on distribution patterns and ecological preferences. Aquat. Sci., 71, 3-14.

Holzenthal R.W. and Hamilton S.W., 1988. New species and records of Costa Rican Polycentropus (Trichoptera: Polycentropodidae). J. N. Y. Entomol. Soc., 96, 332-344.

Holzenthal R.W. and Pes A.M.O., 2004. A new genus of longhorned caddisfly from the Amazon basin (Trichoptera: Leptoceridae: Grumichellini). Zootaxa, 621, 1-16.

Holzenthal R.W., Blahnik R.J., Prather A.L. and Kjer K.M., 2007. Order Trichoptera Kirby, 1813 (Insecta), caddisflies. Zootaxa, 1668, 639-698.

Hurlbert S.H., 1984. Pseudoreplication and the design of ecological field experiments. Ecol. Monogr., 54, 187-211.

Juen L. and De Marco P. Jr., 2011. Odonate biodiversity in terra-firme forest streamlets in Central Amazonia: on the relative effects of neutral and niche drivers at small geographical extents. Insect Conserv. Divers., 4, 1-10.

Juen L., Cabette H.S.R. and De Marco P. Jr., 2007. Odonate assemblage structure in relation to basin and aquatic habitat structre in Pantanal wetlands. Hydrobiologia, 579, 125-134.

Lammert M. and Allan J.D., 1999. Assessing biotic integrity of streams: effects of scale in measuring the influence of land use/cover and habitat structure on fish and macroinvertebrate. Environ. Manage., 23, 257-270.

Martins-Silva M.J., Engel D.W., Rocha F.M. and Araújo J., 2008. Imaturos de Trichoptera na Bacia do Rio Paranã, GO, com novos registros de gênero. Neotrop. Entomol., 37, 735-738. 
Merritt R.W. and Cummins, K.W., 1984. An Introduction to the Aquatic Insects of North America, Kendall/Hunts, Dubuque, $311 \mathrm{p}$.

Nessimian J.L., Venticinque E.M., Zuanon J., De Marco P. Jr., Gordo M., Fidelis L., Batista J.D. and Juen L., 2008. Land use, habitat integrity and aquatic insect assemblages in Central Amazonian streams. Hydrobiologia, 614, 117-131.

Niemi G.J. and McDonald M.E., 2004. Application of ecological indicators. Annu. Rev. Ecol. Evol. Syst., 35, 89-111.

Nogueira D.S., Cabette, H.S.R. and Juen L., 2011. Estrutura e composição da comunidade de Trichoptera (Insecta) de rios e áreas alagadas da bacia do rio Suiá-Miçú, Mato Grosso, Brasil. Iheringia, Sér Zool., 101(3): 173-180.

Oliveira L.G. and Froehlich C.G., 1997. Diversity and community structure of aquatic insects (Ephemeroptera, Plecoptera and Trichoptera) in a southeastern Brazilian mountain stream. Acta Limnol. Bras., 9, 139-148.

Pather A.L., 2003. Revision of the neotropical caddisfly Phylloicus (Trichoptera: Calamoceatidae). Zootaxa, 275, 1-214.

Pes A.M.O., Hamada N. and Nessimian J.L., 2005. Chaves de identificação de larvas para famílias e gêneros de Trichoptera (Insecta), da Amazônia Central, Brasil. Revta Bras. Ent., 49, 181-204.

Pes A.M.O., Hamada N. and Soares C.C., 2008. Description of the last-instar larva and pupa and the bionomics of Smicridea (Smicridea) truncata Flint (Trichoptera: Hydropsychidae) in Central Amazonia, Brazil. Zootaxa, 1732, 54-60.

R Development Core Team, 2010. R: A Language and Environment for Statistical Computing. R Foundation for Statistical Computing, Vienna. Accessed online on June 2010, http://www.rproject.org

Reiso R. and Brittain J.E., 2000. Life cycle, diet and habitat of Polycentropus jlavomaculatus, Plectrocnemia conspevsa and Rhyacophila nubila (Trichoptera) in Ovre Heimdalen, Jotunheimen Mountains, Norway. Norw. J. Entomol., 47, 113-124.

Rosenberg D.M. and Resh V.H., 1993. Introduction to freshwater biomonitoring and benthic macroinvertebrates. In: Rosenberg, D.M. and Resh, V.H. (eds.), Freshwater
Biomonitoring and Benthic Macroinvertebrates, Chapman \& Hall, London, 1-9.

Shimano Y., Cabette H.S.R., Salles F.F. and Juen L., 2010. Composição e distribuição da fauna de Ephemeroptera (Insecta) em área de transição Cerrado - Amazônia, Brasil. Iheringia. Sér. Zool., 100, 301-308.

Silveira M.P., Buss D.F., Nessimian J.L. and Baptista D.F., 2006. Spatial and temporal distribution of benthic macroinvertebrates in a southeastern Brazilian River. Braz. J. Biol., 66, 623-232.

Souza H.M. de L., Juen L. and Cabette H.S.R., 2010. Diversidade beta de Baetidae (Ephemeroptera) em córregos da Bacia Hidrográfica do Rio Pindaíba/MT. In: Santos J.E., Galbiati C. and Moschini L.E. (eds.), Gestão e educação ambiental: água, biodiversidade e cultura, RiMa, São Paulo, 109-123.

Souza, H.M. de L., Cabette, H.S.R. and Juen, L., 2011. Baetidae (Insecta, Ephemeroptera) em córregos do cerrado matogrossense sob diferentes níveis de preservação ambiental. Iheringia, Sér Zool, 101(3): 181-190.

Spies M.R., Froehlich C.G. and Kotzian C.B., 2006. Composition and diversity of Trichoptera (Insecta) larvae communities in the middle section of the Jacuí river and some tributaries, state of Rio Grande do Sul, Brazil. Iheringia, Sér. Zool., 96, 389-983.

Strahler H.N., 1957. Quantitative analysis of watershed geomorphology. Trans. Am. Geophys. Union, 33, 913-920.

Ter Braak C.J.F., 1986. Canonical correspondence analysis: a new eigenvector technique for multivariate direct gradients analysis. Ecology, 67, 1167-1179.

Utz R.M., Hilderbrand R.H. and Boward D.M., 2009. Identifying regional differences in threshold responses of aquatic invertebrates to land cover gradients. Ecol. Indic., 9, $556-567$.

Wiggins G.B., 1996. Larvae of the North American Caddisfly Genera (Trichoptera), University of Toronto Press Incorporated, Toronto, $457 \mathrm{p}$.

Zar J.H., 1999. Biostatistical Analysis (4th edn,), Prentice-Hall, Englewood Cliffs, New York, 630 p. 